\title{
Communication
}

\section{Influence of the 2'-Hydroxyl Group Conformation on the Stability of A-form Helices in RNA}

\author{
Jörg Fohrer ${ }^{1}$, Mirko Hennig ${ }^{2 *}$ and Teresa Carlomagno ${ }^{1 *}$
}

\author{
${ }^{1}$ Department of NMR Based \\ Structural Biology, Max Planck \\ Institute for Biophysical \\ Chemistry, Am Fassberg 11 \\ D-37077 Göttingen, Germany \\ ${ }^{2}$ Department of Molecular \\ Biology, The Scripps Research \\ Institute, MB33, 10550 North \\ Torrey Pines Road, La Jolla \\ CA 92037, USA
}

The 2'-hydroxyl group plays fundamental roles in both the structure and the function of RNA, and is the major determinant of the conformational and thermodynamic differences between RNA and DNA. Here, we report a conformational analysis of 2'-OH groups of the HIV-2 TAR RNA by means of NMR scalar coupling measurements in solution.

Our analysis supports the existence of a network of water molecules spanning the minor groove of an RNA $A$-form helix, as has been suggested on the basis of a high-resolution X-ray study of an RNA duplex. The $2^{\prime}-\mathrm{OH}$ protons of the lower stem nucleotides of the TAR RNA project either towards the $\mathrm{O}^{\prime}$ or towards the base, where the $2^{\prime}-\mathrm{OH}$ group can favorably participate in $\mathrm{H}$-bonding interactions with a water molecule situated in the nucleotide base plane. We observe that the $k_{\text {ex }}$ rate of the $2^{\prime}-\mathrm{OH}$ proton with the bulk solvent anti-correlates with the base-pair stability, confirming the involvement of the $2^{\prime}-\mathrm{OH}$ group in a collective network of $\mathrm{H}$-bonds, which requires the presence of canonical helical secondary structure.

The methodology and conformational analysis presented here are broadly applicable and facilitate future studies aimed to correlate the conformation of the $2^{\prime}-\mathrm{OH}$ group with both the structure and the function of RNA and RNA-ligand complexes.

(C) 2005 Elsevier Ltd. All rights reserved. $A$-form helix stability; scalar coupling

The $2^{\prime}$ - hydroxyl group is a major determinant for both the structure and the function of RNA, where the sugars are all ribose. ${ }^{1}$ The presence of the ribose 2'-hydroxyl group in RNA engenders a preference for the $\mathrm{C}^{\prime}$-endo puckering, thereby providing the decisive factor for the differences in conformation, hydration and thermodynamic stability between canonical RNA and DNA helices. $^{2}$ A high-resolution crystal structure of an RNA duplex revealed the existence of a complex hydration network in the minor groove of the $A$-form helix, ${ }^{3}$ which is supported by the specific distribution of the 2'-hydroxyl groups. The presence of water molecules in the RNA minor groove, anchored by electrostatic interactions to

Abbreviations used: HIV, human immunodeficiency virus; Tat, transcription activator; TAR, transactivation response element; NOE, nuclear Overhauser effect; NOESY, NOE spectroscopy; HSQC, heteronuclear single quantum coherence.

E-mail addresses of the corresponding authors: mirko@scripps.edu; taco@nmr.mpibpc.mpg.de both the ribose and the base, provides an enthalpic contribution to $A$-form helix stability and, additionally, offers a basis for the entropic regulation of ligand binding to the minor groove. Non-canonical RNA structural elements, such as tetraloops and pseudoknots, can be stabilized by H-bonds involving the $2^{\prime}$-hydroxyl group as well. ${ }^{4-10}$ Moreover, the $2^{\prime}$-hydroxyl group has an established role in RNA catalysis. Numerous examples of the role of the 2'-hydroxyl group in catalytic RNAs are documented for self-splicing viral ribozymes, type II introns and the pre-mRNA processing machinery. ${ }^{11-14}$ Despite the importance of the 2'-hydroxyl group in RNA structure stabilization and function, only limited structural data is available for the $2^{\prime}-\mathrm{OH}$ proton of RNA. $2,7,15,16$

Hydrogen atoms are not directly observable in crystal structures; in aqueous solution the rapid exchange of the hydroxyl proton with the solvent typically prevents its observation in RNA at room temperature by NMR. Consequently, in the absence of structural information on the $2^{\prime}-\mathrm{OH}$ proton, the torsion angle $\theta\left(\mathrm{H}^{\prime}-\mathrm{C}^{\prime}-\mathrm{O} 2^{\prime}-\mathrm{H}\right)$ 
remains undetermined. Molecular dynamics (MD) simulations of an RNA hairpin identified three energetically preferred orientations that the $2^{\prime}$ hydroxyl proton can assume if a ribose sugar adopts a $\mathrm{C}^{\prime}$-endo pucker (as is the case in canonical RNA $A$-form helix, Figure 1): ${ }^{17}$ (A) toward the $\mathrm{O}^{\prime}$, stabilized by attractive electrostatic interaction with the phosphate backbone $\left(\mathrm{O}^{\prime}\right.$ domain), (B) toward the $\mathrm{O}^{\prime}$, stabilized by favorable intra-ribose electrostatic interactions $\left(\mathrm{O}^{\prime}{ }^{\prime}\right.$ domain), and (C) toward the base, stabilized by electrostatic interaction with the N3 or O2 atom of the attached base (base domain).

Recently, we have reported almost complete resonance assignments of the $2^{\prime}$-hydroxyl protons of the 30mer human immunodeficiency virus (HIV)2 transactivation response element (TAR) RNA in aqueous solution at low temperature. ${ }^{18}$ The HIV transcription activator (Tat)-TAR complex formation provides an essential transcription regulatory function for HIV. The lentiviral protein Tat binds the TAR hairpin located at the $5^{\prime}$-end of nascent viral transcripts and thereby enhances the inefficient elongation of transcription complexes initiated at the HIV promoter. The cellular RNA-polymerase II (RNAP II) is able to transcribe the entire viral RNA only when Tat is bound to TAR. ${ }^{19}$

The NMR resonance assignment has been obtained using two-dimensional homonuclear total correlated spectroscopy (TOCSY) ${ }^{20}$ and nuclear Overhauser effect spectroscopy (NOESY) ${ }^{21}$ experiments at $5{ }^{\circ} \mathrm{C}$. A semi-quantitative analysis of the NOESY cross-peak intensities revealed several NOEs of medium intensity between the $2^{\prime}-\mathrm{OH}$ and the $\mathrm{H} 1^{\prime}$ protons, in contrast to previous studies, ${ }^{15}$ which reported mostly weak $2^{\prime}-\mathrm{OH}$ to $\mathrm{H}^{\prime}$ proton NOEs in an RNA duplex. Most notably, we readily observed several 2'-OH(i)-H6/H8 $(i+1)$ crosspeaks of weak intensity, which are compatible with the $2^{\prime}-\mathrm{OH}$ proton either in the base domain

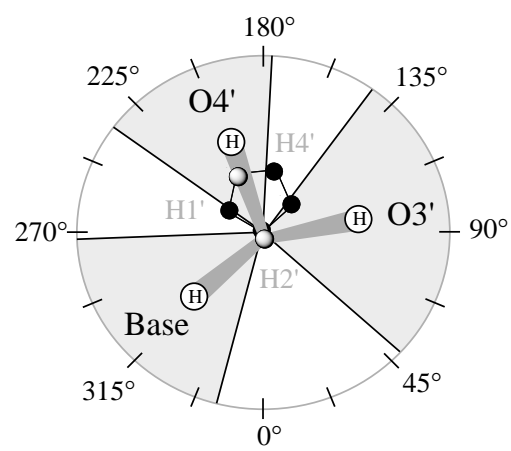

Figure 1. Energetically favored orientations of the $2^{\prime}-$ hydroxyl group when the ribose is in the $\mathrm{C} 3^{\prime}$-endo conformation. The ribose sugar ring is schematically shown in the middle with oxygen atoms in grey and carbon atoms in black. According to MD simulations, ${ }^{17}$ the torsion angle $\theta=\left(\mathrm{H} 2^{\prime}-\mathrm{C}^{\prime}-\mathrm{O} 2^{\prime}-\mathrm{H}\right)$ can populate three regions, highlighted in grey: the $\mathrm{O}^{\prime}$ domain, torsion angle $\theta=$ $50^{\circ}-140^{\circ}$; the $\mathrm{O} 4^{\prime}$ domain, torsion angle $\theta=175^{\circ}-230^{\circ}$; the base domain, torsion angle $\theta=270^{\circ}-345^{\circ}$. or in a small region of the $\mathrm{O}^{\prime}$ domain $\left(\mathrm{H} 2^{\prime}-\mathrm{C} 2^{\prime}-\right.$ $\mathrm{O} 2^{\prime}-\mathrm{H}$ torsion angle $\theta \approx 60^{\circ}$ ).

Experimental determination of the $2^{\prime}$-hydroxyl proton location in RNA structures is essential to verify the role of the 2'-hydroxyl group in the stabilization of RNA folding motifs. Here, we present a conformational analysis of the torsion angle $\mathrm{H} 2^{\prime}-\mathrm{C}^{\prime}-\mathrm{O} 2^{\prime}-\mathrm{H}$ in the HIV-2 TAR RNA based on the measurement of the three scalar couplings between the $2^{\prime}-\mathrm{OH}$ proton and the $\mathrm{H} 2^{\prime}, \mathrm{C}^{\prime}{ }^{\prime}$ or $\mathrm{C}^{\prime}$ ribose nuclei $\left({ }^{3} J_{\mathrm{H} 2^{\prime}-2^{\prime} \mathrm{OH}},{ }^{3} J_{\mathrm{C}^{\prime}-2^{\prime} \mathrm{OH}}\right.$ and $\left.{ }^{3} J_{\mathrm{C}^{\prime}-2^{\prime} \mathrm{OH}}\right)$. To the best of our knowledge, this work represents the first thorough conformational analysis of the $2^{\prime}$ hydroxyl group in a medium-sized RNA; all previous conformational studies on the $\mathrm{H}^{\prime}-\mathrm{C}^{\prime}-$ $\mathrm{O} 2^{\prime}-\mathrm{H}$ torsion angle via scalar couplings were conducted on either single nucleotides in $\mathrm{DMSO}^{22,23}$ or targeted a single $2^{\prime}$-hydroxyl group stabilizing a UUCG-tetraloop. ${ }^{7}$ The NMR techniques presented here provide a uniformly applicable way to study the orientation of the $2^{2}-\mathrm{OH}$ group in RNA in solution, thereby allowing association of the 2'-hydroxyl group conformation with specific RNA functions, such as RNA catalysis.

The homonuclear and heteronuclear ${ }^{3} \mathrm{~J}_{\mathrm{H} 2^{\prime}-2^{\prime} \mathrm{OH}}$ ${ }^{3} J_{\mathrm{C}^{\prime}-2^{\prime} \mathrm{OH}}$ and ${ }^{3} \mathrm{~J}_{\mathrm{C}^{\prime}-2^{\prime} \mathrm{OH}}$ scalar couplings of the HIV2 TAR RNA have been measured in specifically tailored two-dimensional NMR experiments using the quantitative $J$ approach. ${ }^{24}$ Briefly, the ${ }^{3} J_{\mathrm{H}^{\prime}-2^{\prime} \mathrm{OH}}$ couplings were measured in a $\mathrm{H}^{\prime}-\mathrm{H}_{\text {base }} \mathrm{NOESY}$ correlation experiment (Figure 2(a)). We chose this correlation for its highly efficient NOESY transfer and adequate resolution. It should be mentioned that this experiment benefited from the use of a $0.7 \mathrm{mM}$ HIV-2 TAR RNA sample consisting of d4-nucleotides lacking all but $\mathrm{H}^{\prime}$ and $\mathrm{H} 2^{\prime}$ ribose protons. ${ }^{25}$ This specific deuteration pattern allows for selective detection of the $\mathrm{H}^{\prime}-\mathrm{H}_{\text {base }} \mathrm{NOEs}$ with high sensitivity, while circumventing overlap with other $\mathrm{H}_{\text {ribose }}-\mathrm{H}_{\text {base }}$ NOEs. In the absence of a selectively deuterated sample, a three-dimensional ${ }^{13} \mathrm{C}$-edited NOESY correlation is necessary to achieve the desired resolution of the $\mathrm{H} 2^{\prime}-\mathrm{H}_{\text {base }}$ peaks. The ${ }^{3} J_{\mathrm{C}^{\prime}-2^{\prime} \mathrm{OH}}$ and ${ }^{3} J_{\mathrm{C}^{\prime}-2^{\prime} \mathrm{OH}}$ scalar couplings were measured in constant-time $\mathrm{C}^{\prime}-\mathrm{H} 1^{\prime}$ (Figure 2(b)) and $\mathrm{C}^{\prime}-\mathrm{H}^{\prime}{ }^{\prime} \mathrm{HSQC}$ correlations, respectively.

The ${ }^{3} \mathrm{H}_{\mathrm{H} 2^{\prime}-2^{\prime} \mathrm{OH}}$ couplings measured for the HIV-2 TAR RNA at $5{ }^{\circ} \mathrm{C}$ are shown in Figure 3(a). In general, the ${ }^{3} \mathrm{~J}_{\mathrm{H}^{\prime}-2^{\prime} \mathrm{OH}}$ couplings cluster between $3 \mathrm{~Hz}$ and $4.5 \mathrm{~Hz}$ and, except for $\mathrm{C} 18$, no value exceeds $5.5 \mathrm{~Hz}$. Chemical exchange of the $2^{\prime}-\mathrm{OH}$ proton with the solvent can potentially reduce apparent ${ }^{3} \mathrm{~J}_{\mathrm{H} 2^{\prime}-2^{\prime} \mathrm{OH}}$ coupling values. We determined the exchange rate constant $k_{\text {ex }}$ of the $2^{\prime}-\mathrm{OH}$ protons with bulk water for $\mathrm{C} 19$ from the intensity of the exchange cross-peak in NOESY spectra at $1^{\circ} \mathrm{C}, 5^{\circ} \mathrm{C}$ and $10^{\circ} \mathrm{C}$. The measured $k_{\text {ex }}$ value for $\mathrm{C} 19$ of approximately $15 \mathrm{~Hz}$ at $5^{\circ} \mathrm{C}$ is in good agreement with the value reported by Gyi et al. for an RNA and an RNA-DNA duplex. ${ }^{2}$ Unfortunately, severe overlap of the remaining $2^{\prime}-\mathrm{OH}$ proton resonances impeded the accurate determination of the $k_{\mathrm{ex}}$ values for the other nucleotides. 
(a)

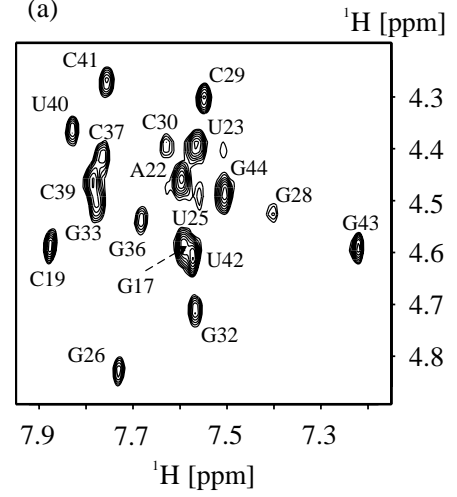

(b)

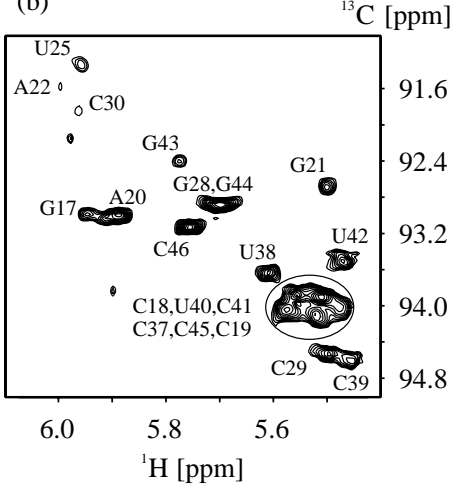

(c)

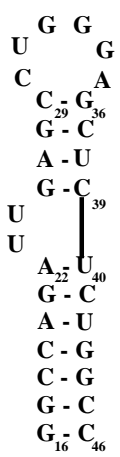

Figure 2. Spectra were recorded on $0.6 \mathrm{mM} 3^{\prime}, 4^{\prime}, 5^{\prime}, 5^{\prime \prime}$-d4-HIV-2 TAR RNA, where all ribose protons but the $\mathrm{H}^{\prime}$ and $\mathrm{H} 2^{\prime}$ were replaced by deuterons. The sample buffer contained $10 \mathrm{mM}$ phosphate $(\mathrm{pH} 6.4)$, $50 \mathrm{mM}$ sodium chloride, and $0.1 \mathrm{mM}$ EDTA in $500 \mu \mathrm{l}$ of $90 \%$ $\mathrm{H}_{2} \mathrm{O} / 10 \%{ }^{2} \mathrm{H}_{2} \mathrm{O}$. The spectra were recorded on a Bruker $800 \mathrm{MHz}$ spectrometer equipped with a $z$-gradient triple-resonance probe, processed with the NMRPipe program and analyzed using FELIX 2000 (MSI, San Diego, USA).

(a) Cross experiment of the $\mathrm{H}_{2}^{\prime}(i)-\mathrm{H} 6 / 8(i+1)$ NOESY correlation for the measurement of the ${ }^{3} \mathrm{JH}_{\mathrm{H}^{\prime}-2^{\prime} \mathrm{OH}}$ couplings. In the cross experiment, we employed a constant time delay of $40 \mathrm{~ms}$, during which the $\mathrm{H} 2^{\prime}$ proton magnetization is transversal and subjected to J-dephasing effects, which results in measurable attenuation of the observed $\mathrm{H}^{\prime}{ }^{\prime}-\mathrm{H}_{\text {base }}$ cross-peaks. In the reference experiment, the evolution of the vicinal ${ }^{3} J_{\mathrm{H} 2^{\prime}-2^{\prime} \mathrm{OH}}$ coupling is refocused by use of a REBURP pulse $^{36}$ of duration $4 \mathrm{~ms}$ centered at $4.16 \mathrm{ppm}$. This pulse selectively refocuses the $\mathrm{H} 2^{\prime}$ protons at a proton resonance frequency of $800 \mathrm{MHz}$, without affecting the $2^{\prime} \mathrm{OH}$ and the $\mathrm{H}^{\prime}$ resonances (excitation bandwidth, $\pm 550 \mathrm{~Hz}$; transition region, $250 \mathrm{~Hz}$ ). In contrast, the ${ }^{3} \mathrm{~J}_{\mathrm{H}^{\prime}-2^{\prime} \mathrm{OH}}$ coupling is active during the cross experiment by simultaneous application of the H2' REBURP pulse and of a 4 ms IBURP pulse ${ }^{36}$ centered in the $2^{\prime}$-OH region at $6.97 \mathrm{ppm}$ in the center of the constant time period. The IBURP pulse selectively inverts the $2^{\prime}-\mathrm{OH}$ protons leaving the resonances of the $\mathrm{H}^{\prime}$ protons unaffected on an $800 \mathrm{MHz}$ spectrometer (excitation bandwidth, $\pm 550 \mathrm{~Hz}$; transition region, $250 \mathrm{~Hz}$ ). (b) Expansion of the cross spectrum of the $\mathrm{C} 1^{\prime}-\mathrm{H} 1^{\prime} \mathrm{CT}-\mathrm{HSQC}$ for the measurement of the heteronuclear ${ }^{3} J_{\mathrm{C} 1^{\prime}-2^{\prime} \mathrm{OH}}$. Analogously, a C $3^{\prime}-\mathrm{H} 3^{\prime} \mathrm{CT}-$ HSQC was used for the measurement of the ${ }^{3} J_{\mathrm{C}^{\prime}-2^{\prime} \mathrm{OH}}$. Evolution of the ${ }^{3} J_{\mathrm{C}^{\prime}-2^{\prime} \mathrm{OH}}$ and ${ }^{3} J_{\mathrm{C}^{\prime}-2^{\prime} \mathrm{OH}}$ scalar couplings during the constant time of the cross experiment was achieved by simultaneous application of a carbon pulse and a $4 \mathrm{~ms}$ IBURP pulse centered in the $2^{\prime}-\mathrm{OH}$ region at $7.3 \mathrm{ppm}$. A constant time period of $25 \mathrm{~ms}$ was used to achieve optimal sensitivity and resolution for both the $\mathrm{C}^{\prime}-\mathrm{H}^{\prime}$ and the $\mathrm{C}^{\prime}-\mathrm{H}^{\prime}$ correlations. The J-coupling constants were extracted from the intensity ratio of peaks in the cross and reference experiments, according to equation (1): ${ }^{24}$

$$
\frac{I_{\text {cross }}}{I_{\text {ref }}}=\cos (\pi J T)
$$

where $T$ is the length of the constant time period. It should be noted that the effective J-evolution periods employed in the calculations are compensated for the evolution of the couplings during the IBURP pulses, which resulted in constant times of $34.76 \mathrm{~ms}, 22.05 \mathrm{~ms}, 22.05 \mathrm{~ms}$ for the three ${ }^{3} \mathrm{~J}_{\mathrm{H}^{\prime}-2^{\prime} \mathrm{OH}}{ }^{3} J_{\mathrm{C}^{\prime}-2^{\prime} \mathrm{OH}}$ and ${ }^{3} J_{\mathrm{C}^{\prime}-2^{\prime} \mathrm{OH}}$ scalar couplings, respectively. (c) Secondary structure of the HIV-2 TAR RNA.

When a substantially larger $k_{\mathrm{ex}}=25 \mathrm{~Hz}$ is assumed, the apparent ${ }^{3} J_{\mathrm{H} 2^{\prime}-2^{\prime} \mathrm{OH}}$ coupling measured over a $40 \mathrm{~ms}$ long constant time is approximately $85 \%$ of the actual ${ }^{3} \mathrm{~J}_{\mathrm{H}^{\prime}-2^{\prime} \mathrm{OH}}$ coupling. For the majority of nucleotides, however, this $15 \%$ tolerance would be well within the limits of the experimental error. Thus, for $k_{\mathrm{ex}}$ up to $25 \mathrm{~Hz}$, we could consider the effective $J$-coupling scaling factor from solvent exchange to be negligible.

The stability of RNA structures can fluctuate locally. Consequently, in order to locate secondary structural elements within the TAR RNA structure (Figure 2(c)), where ${ }^{3} \mathrm{~J}_{\mathrm{H} 2^{\prime}-2^{\prime} \mathrm{OH}}$ couplings are considerably influenced by solvent exchange, we carefully compared the ${ }^{3} \mathrm{~J}_{\mathrm{H} 2^{\prime}-2^{\prime} \mathrm{OH}}$ coupling values obtained at $5^{\circ} \mathrm{C}$ and $1{ }^{\circ} \mathrm{C}$. Substantial differences in the ${ }^{3} \mathrm{~J}_{\mathrm{H} 2^{\prime}-2^{\prime} \mathrm{OH}}$ couplings at $5{ }^{\circ} \mathrm{C}$ and $1{ }^{\circ} \mathrm{C}$ are expected for nucleotides with $k_{\mathrm{ex}}>1 / T$ ( $T$ being the length of the constant time period). No significant modulation is expected for nucleotides with $k_{\mathrm{ex}} \leq 1 / T$.

The results from this comparison are striking. The ${ }^{3} \mathrm{~J}_{\mathrm{H} 2}{ }^{\prime}-2^{\prime} \mathrm{OH}$ coupling values of canonical WatsonCrick C-G or G-C base-pairs of the lower stem remain the same at $5{ }^{\circ} \mathrm{C}$ and $1{ }^{\circ} \mathrm{C}$ within exper- imental error. Coupling values of nucleotides A20, $\mathrm{U} 40$, and U42, of all nucleotides located in the shorter upper stem, and of the loop nucleotide C30 experience increases ranging from $30 \%$ to $50 \%$ when the temperature is decreased from $5{ }^{\circ} \mathrm{C}$ to $1^{\circ} \mathrm{C}$. Surprisingly, the ${ }^{3} \mathrm{H}_{\mathrm{H} 2^{\prime}-2^{\prime} \mathrm{OH}}$ couplings of bulged nucleotides U23 and U25 do not change as a function of temperature. This clearly indicates that the $k_{\text {ex }}$ rate of these nucleotides is similar to the $k_{e x}$ rate of canonical CG base-pairs.

Taken together, our results strongly suggest a correlation between $2^{\prime}-\mathrm{OH}$ proton solvent exchange rates $k_{\mathrm{ex}}$ and base-pair opening rates (probed by imino proton exchange) in canonical $A$-form helical structures. The exchange process of $\mathrm{H}$-bonded imino protons with solvent can be qualitatively explained on the basis of a two-state model involving open and closed states of Watson-Crick pairs. If it assumed that the closed $A$-form geometry is stabilized by an ordered series of hydrogen bonds involving the ribose 2 '-hydroxyl group, the functional groups within the bases, and water molecules bound in the minor groove, we speculate that the transient opening of the base-pair favors the exchange of bound water with the bulk solvent, 
(a)

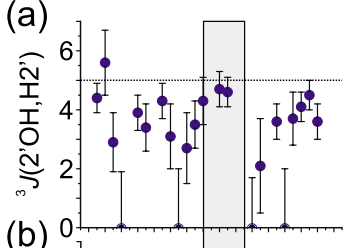

(b)

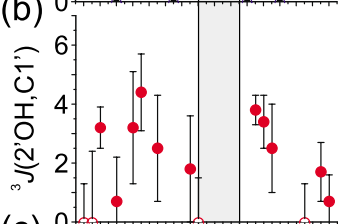

(c) 0

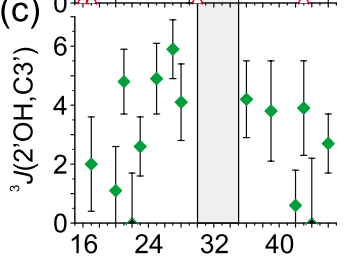

(d)

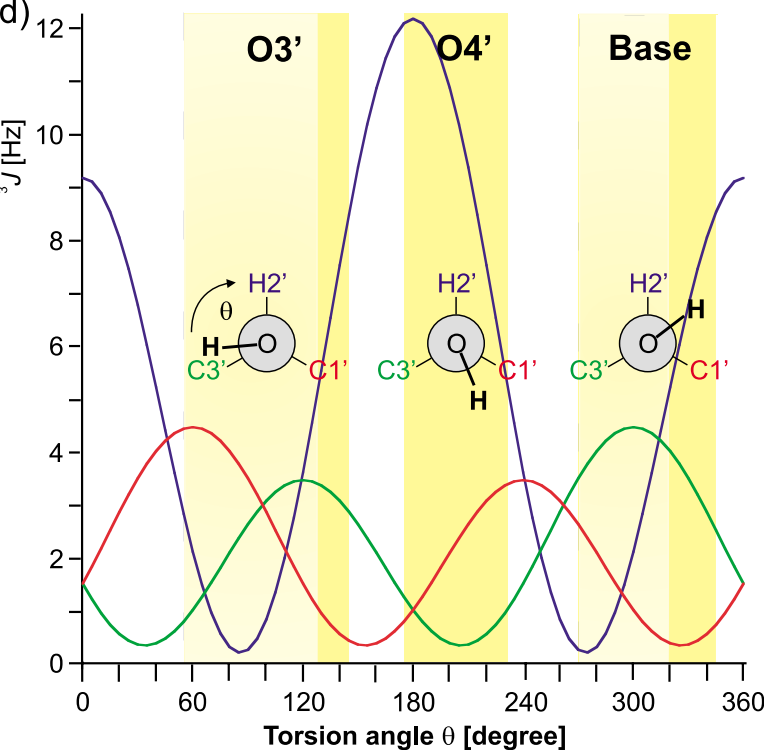

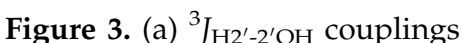
measured at $5{ }^{\circ} \mathrm{C}$ employing the quantitative- $J\left(\mathrm{H}_{2}{ }_{i}-\mathrm{H} 6 / 8_{i+1}\right) \mathrm{CT}$ NOESY experiment. The dotted line indicates ${ }^{3} \mathrm{~J}_{\mathrm{H}^{\prime}-2^{\prime} \mathrm{OH}}=5.0 \mathrm{~Hz}$. (b) ${ }^{3} \mathrm{~J}_{\mathrm{C}^{\prime}-2^{\prime} \mathrm{OH}}$ couplings obtained at $5{ }^{\circ} \mathrm{C}$ using the quantitative- $J$ $\left(\mathrm{C}^{\prime}{ }_{i}-\mathrm{H} 1^{\prime}\right)$ CT-HSQC experiment. (c) ${ }^{3} J_{\mathrm{C}^{\prime}-2^{\prime} \mathrm{OH}}$ couplings obtained at $5{ }^{\circ} \mathrm{C}$ from the quantitative- $J\left(\mathrm{C}^{\prime}{ }_{i}-\right.$ H1) CT-HSQC experiment. Apical hexaloop nucleotides are shaded in grey. (d) Karplus-like dependence of the homonuclear ${ }^{3} \mathrm{~J}_{\mathrm{H}^{\prime}-2^{\prime} \mathrm{OH}} \mathrm{coup}-$ ling (blue line) on the torsion angle $\theta\left(\mathrm{H}^{\prime}-\mathrm{C}^{\prime}-\mathrm{O} 2^{\prime}-\mathrm{H}\right)$ according to Fraser et al. ${ }^{30}$ No Karplus parameterization is available for the heteronuclear ${ }^{3} J_{\mathrm{C}^{\prime}-2^{\prime} \mathrm{OH}}$ and the ${ }^{3} \mathrm{~J}_{\mathrm{C}^{\prime}-2^{\prime} \mathrm{OH}}$ couplings. The red and green lines for the ${ }^{3} \mathrm{C}_{\mathrm{C}^{\prime}-2^{\prime} \mathrm{OH}}$ and the ${ }^{3} J_{\mathrm{C}^{\prime}-2^{\prime} \mathrm{OH}}$ couplings, respect-

ively, represent approximated Karplus curves derived by scaling the coefficients of the ${ }^{3} J_{\mathrm{C}-\mathrm{H}}$ Karplus-relation in alkenes $\left({ }^{3} J_{\mathrm{C}-\mathrm{H}}=3.6 \cos 2 \phi-1.0 \cos \phi+4.3\right)$ to reflect the averaged value of the ${ }^{3} \mathrm{~J}_{\mathrm{C}-\mathrm{OH}}$ coupling in ethanol $(2.9 \mathrm{~Hz}){ }^{31} \mathrm{We}$ assume equal populations of the trans, gauche + and gauche - conformations for ethanol. Neither the difference in the substituents of the $\mathrm{C}^{\prime}$ and $\mathrm{C}^{\prime}$ nuclei nor the fact that these nuclei are part of a conformational restricted ring system are considered in this approximation; therefore the Karplus-relations for the ${ }^{3} J_{\mathrm{C}^{\prime}-2^{\prime} \mathrm{OH}}$ or the ${ }^{3} J_{\mathrm{C}^{\prime}-2^{\prime} \mathrm{OH}}$ couplings represent crude approximations. Boxed yellow areas correspond to the energetically favored orientational domains (OO3 $3^{\prime}, \mathrm{O}^{\prime}{ }^{\prime}$, and base, respectively) of the 2'-hydroxyl group, according to Auffinger and Westhof (see also Figure 1). ${ }^{17}$ The pale yellow delimits the regions of these domains where the ${ }^{3} \mathrm{~J}_{\mathrm{H}^{\prime}-2^{\prime} \mathrm{OH}}$ coupling is less than $5.0 \mathrm{~Hz}$.

thereby directly influencing the $k_{\text {ex }}$ rate of the $2^{\prime}-\mathrm{OH}$ proton. Imino protons can only exchange with bulk water from transiently opened conformations through acid-base reactions catalyzed by proton acceptors; they are protected when engaged in a closed base-pair. ${ }^{26,27}$ Base-pair opening events can occur via two pathways as revealed by MD simulations. ${ }^{28,29}$ Both major and minor groove opening are feasible with the major groove pathway being energetically slightly more favorable.

Our hypothesis of correlated imino and 2'-OH proton exchange is supported by the fact that the base-pair lifetimes of RNA A-U base-pairs in the $A$-form helix geometry are substantially shorter than those of G-C base-pairs. ${ }^{26,27}$ Subsequently, only the cytidine and guanosine residues of the lower stem and the two bulged uridine residues were further considered in the quantitative evaluation of the ${ }^{3} \mathrm{H}_{\mathrm{H}^{\prime}-2^{\prime} \mathrm{OH}},{ }^{3} \mathrm{Cl}_{\mathrm{C}^{\prime}-2^{\prime} \mathrm{OH}}$ and ${ }^{3} J_{\mathrm{C}^{\prime}-2^{\prime} \mathrm{OH}}$ scalar couplings.

A Karplus curve showing the dependence of the ${ }^{3} J_{\mathrm{H}^{\prime}-2^{\prime} \mathrm{OH}}$ on the intervening torsion angle $\mathrm{H} 2^{\prime}-\mathrm{C}^{\prime}{ }^{\prime}-$ $\mathrm{O} 2^{\prime}-2^{\prime} \mathrm{OH}$ is shown in Figure 3(d) (blue line). ${ }^{30}$ The upper limit of $5.5 \mathrm{~Hz}$ observed for the nucleotides of the lower stem excludes the possibility that any of these $2^{\prime}-\mathrm{OH}$ groups occupy the $\mathrm{O}^{\prime}$ domain. This observation indicates that the $2^{\prime}-\mathrm{OH}$ is not involved in intra-ribose $2^{\prime}-\mathrm{OH}-\mathrm{O} 4^{\prime}$ electrostatic interactions, but rather contacts either the base $(2$ '-OH conformation in the base domain) or the phosphate backbone ( $\mathrm{O}^{\prime}$ domain). The absence of $2^{\prime}-\mathrm{OH}$ protons in the $\mathrm{O}^{\prime}$ domain in canonical $A$-form helical structure of the lower stem in the TAR RNA is consistent with our semi-quantitative analysis of detectable NOE cross-peaks in a short mixing time 2D NOESY experiment $\left(\tau_{\mathrm{m}}=50 \mathrm{~ms}\right) .^{18}$ Even at $1{ }^{\circ} \mathrm{C}$, only the ${ }^{3} \mathrm{JH}_{\mathrm{H}^{\prime}-2^{\prime} \mathrm{OH}}$ of residue $\mathrm{C} 30$ reaches $7 \mathrm{~Hz}$, while larger values $(>8 \mathrm{~Hz})$ of the ${ }^{3} J_{\mathrm{H}^{\prime}-2^{\prime} \mathrm{OH}}$ associated with a significant portion of the $\mathrm{O}^{\prime}$ domain, are never observed.

The heteronuclear ${ }^{3} \mathrm{C}_{\mathrm{C}^{\prime}-2^{\prime} \mathrm{OH}}$ couplings proved to be difficult to measure due to the limited resolution of the $\mathrm{C} 1^{\prime}-\mathrm{H} 1^{\prime}$ correlation in canonical $A$-form geometry (Figure 3(b)). Moreover, eight out of 29 carbon atoms (G26, A27, U31, G32, G33, G34, A35 and G36) are not observed at $5{ }^{\circ} \mathrm{C}$, which can be attributed to interconverting $\mathrm{C}^{\prime}{ }^{\prime}$-endo and $\mathrm{C}^{\prime}{ }^{\prime}$-endo sugar puckers. Those nucleotides are located predominantly in the apical hexanucleotide loop and assume averaged ${ }^{3} J_{\mathrm{H}^{\prime}-\mathrm{H} 2^{\prime}}$ coupling values at elevated temperatures $\left(25^{\circ} \mathrm{C}\right)$, indicative of fast exchange between $\mathrm{C}^{\prime}$-endo and $\mathrm{C}^{\prime}$-endo sugar puckers. With the exception of residue U23, all measurable heteronuclear ${ }^{3} \mathrm{~J}_{\mathrm{C}^{\prime}-2^{\prime} \mathrm{OH}}$ couplings are smaller than $4 \mathrm{~Hz}$, with nucleotides in the lower stem exhibiting particularly small values $\left({ }^{3} J_{\mathrm{C}^{\prime}-2^{\prime} \mathrm{OH}} \leq 3 \mathrm{~Hz}\right)$. Due to their small size, the achievable precision for the ${ }^{3} J_{\mathrm{C}^{\prime}-2^{\prime} \mathrm{OH}}$ coupling measurements is limited, as evident from inspecting the relatively high error bars.

Similarly, resonance overlap and the absolute coupling size affect the measurement of the heteronuclear ${ }^{3} J_{\mathrm{C}^{\prime}-2^{\prime} \mathrm{OH}}$ couplings (Figure 3(c)) using the $\mathrm{C}^{\prime}-\mathrm{H}^{\prime}{ }^{\prime}$ correlation. The observed ${ }^{3} J_{\mathrm{C}^{\prime}-}$ $2^{\prime} \mathrm{OH}$ couplings are, on average, larger than the corresponding ${ }^{3} \mathrm{C}_{\mathrm{C}^{\prime}-2^{\prime} \mathrm{OH}}$ couplings. Again, the smallest values are observed for the nucleotides in 
the lower stem. Interestingly, the $\mathrm{C}^{\prime}-\mathrm{H} 3^{\prime}$ crosspeaks of the apical hexaloop nucleotides do not disappear due to the conformational exchange of the ribose but considerably decrease in intensity. Therefore, the loop nucleotide ${ }^{3} J_{\mathrm{C}^{\prime}-2^{\prime} \mathrm{OH}}$ couplings are characterized by large errors and are not reported here.

Unfortunately, no Karplus parameterization is available for either one of the heteronuclear J-couplings, ${ }^{3} J_{\mathrm{C}^{\prime}-2^{\prime} \mathrm{OH}}$ or ${ }^{3} J_{\mathrm{C}^{\prime}-2^{\prime} \mathrm{OH}}$. However, an approximated Karplus curve for the ${ }^{3} J_{\mathrm{C}^{\prime}-2^{\prime} \mathrm{OH}}$ and the ${ }^{3} J_{\mathrm{C}^{\prime}-2^{\prime} \mathrm{OH}}$ coupling can be obtained (Figure 3(d), red and green lines) by scaling the coefficients for ${ }^{3} J_{\mathrm{C}-\mathrm{H}}$ couplings in alkenes $\left({ }^{3} J_{\mathrm{C}-\mathrm{H}}=3.6 \cos 2 \phi-\right.$ $1.0 \cos \phi+4.3)$ such that they are consistent with the averaged value of the ${ }^{3} J_{\mathrm{C}-\mathrm{OH}}$ coupling observed in ethanol $(2.9 \mathrm{~Hz}){ }^{31}$ Evidently, neither the difference in the substituents of the $\mathrm{C}^{\prime}{ }^{\prime}$ and $\mathrm{C} 3^{\prime}$ nuclei nor the fact that these nuclei are part of a conformationally restricted ribose ring is considered in this crude estimate; therefore, this approximated Karplus relation as shown in Figure 3(d) should not be used to quantitatively interpret the ${ }^{3} J_{\mathrm{C}^{\prime}-2^{\prime} \mathrm{OH}}$ or the ${ }^{3} \mathrm{C}_{\mathrm{C}^{\prime}-2^{\prime} \mathrm{OH}}$ couplings. A qualitative inspection of the approximated Karplus curves nevertheless permits us to assume that ${ }^{3} J_{\mathrm{C}^{\prime}-2^{\prime} \mathrm{OH}}<{ }^{3} J_{\mathrm{C}^{\prime}-2^{\prime} \mathrm{OH}}$ in the base domain and in the region of the $\mathrm{O} 3^{\prime}$ domain where $\theta>90^{\circ}$, whereas ${ }^{3} J_{\mathrm{C}^{\prime}-2^{\prime} \mathrm{OH}}<{ }^{3} J_{\mathrm{C}^{\prime}-2^{\prime} \mathrm{OH}}$ in the region of the $\mathrm{O}^{\prime}$ domain with $\theta>90^{\circ}$.

Subsequently, we performed a detailed conformational analysis of the $\theta\left(\mathrm{H}_{2}^{\prime}-\mathrm{C}^{\prime}-\mathrm{O} 2^{\prime}-\mathrm{H}\right)$ torsion angle for the cytidine and guanosine residues located in the lower stem of the TAR RNA and of bulged uridine residues using a combination of three ${ }^{3} J_{\mathrm{H} 2^{\prime}-2^{\prime} \mathrm{OH}},{ }^{3} J_{\mathrm{C}^{\prime}-2^{\prime} \mathrm{OH}}$ and ${ }^{3} J_{\mathrm{C}^{\prime}-2^{\prime} \mathrm{OH}}$ scalar couplings and the NOE data. The nucleotides located in the upper stem and the AU base-pairs of the lower stem were not included in the analysis because the aforementioned rapid exchange of the $2^{\prime}-\mathrm{OH}$ with the solvent renders those J-coupling values meaningless. The nucleotides of the hexanucleotide loop were not considered either due to the apparent intermediate conformational exchange between the $\mathrm{C}^{\prime}$-endo and the $\mathrm{C} 3^{\prime}$-endo pucker of the ribose.

Our conformational analysis is based on the following criteria: (1) quantitative interpretation of the homonuclear ${ }^{3} \mathrm{~J}_{\mathrm{H} 2^{\prime}-2^{\prime} \mathrm{OH}}$ scalar coupling according to the available Karplus parametrization; ${ }^{30}$ (2) semi-quantitative interpretation of the relative magnitude of the heteronuclear ${ }^{3} \mathrm{~J}_{\mathrm{C}^{\prime}-2^{\prime} \mathrm{OH}}$ and ${ }^{3} J_{\mathrm{C}^{\prime}-2^{\prime} \mathrm{OH}}$ scalar couplings; (3) existence of the $2^{\prime}-\mathrm{OH}(i)-\mathrm{H} 6 /$ $\mathrm{H} 8(i+1)$ NOE cross-peak restricting the conformational space of the $2^{\prime}-\mathrm{OH}$ proton to the base domain or to a small region of the $\mathrm{O}^{\prime}$ domain $\left(\theta \approx 60^{\circ}\right)$.

For example, residue G17 shows a weak $2^{\prime}-\mathrm{OH}(i)-\mathrm{H} 6 / \mathrm{H} 8(i+1)$ NOE cross-peak, which, taken together with the value of the ${ }^{3} J_{\mathrm{H}^{\prime}-2^{\prime} \mathrm{OH}}$ coupling, permits the intervening torsion angle $\theta$ to be either $\theta \approx 45^{\circ}$ or $\theta \approx 315^{\circ}$; a final comparison of the ${ }^{3} \mathrm{~J}_{\mathrm{C}^{\prime}-2^{\prime} \mathrm{OH}}$ and ${ }^{3} \mathrm{~J}_{\mathrm{C}^{\prime}-2^{\prime} \mathrm{OH}}$ scalar coupling magnitudes allows us to discriminate between the two alternative solutions and rotates the torsion angle $\theta$ of $\mathrm{G} 17$ into the base domain $\left(\theta \approx 315^{\circ}\right)$.

A schematic representation of the results obtained from this analysis for the nucleotides of the lower stem of the TAR-RNA is shown in Figure 4(a). The conformation of the $2^{\prime}-\mathrm{OH}$ groups of G17 and C45 is found in the base domain, as indicated by the presence of the $2^{\prime}-\mathrm{OH}(i)-\mathrm{H} 6 /$ $\mathrm{H} 8(i+1) \mathrm{NOE}$ and by the relatively small value of the ${ }^{3} J_{\mathrm{C}^{\prime}-2^{\prime} \mathrm{OH}}$ coupling. The $2^{\prime}-\mathrm{OH}$ groups of $\mathrm{C} 18$, $\mathrm{U} 23$, and G44 adopt an orientation within the $\mathrm{O}^{\prime}$ domain with the torsion angle $\theta \approx 60^{\circ}$, corroborated by the presence of the $2^{\prime}-\mathrm{OH}(i)-\mathrm{H} 6 / \mathrm{H} 8(i+1) \mathrm{NOE}$, the high value of the ${ }^{3} J_{\mathrm{C}^{\prime}-2^{\prime} \mathrm{OH}}$ coupling, and/or the small ${ }^{3} \mathrm{~J}_{\mathrm{C}^{\prime}-2^{\prime} \mathrm{OH}}$ coupling. G21, U25, C41 and G43 project the $2^{\prime}-\mathrm{OH}$ group towards the $\mathrm{O}^{\prime}$ oxygen atom with $\theta \approx 120^{\circ}$, as indicated by the absence of the $2^{\prime}-\mathrm{OH}(i)-\mathrm{H} 6 / \mathrm{H} 8(i+1) \mathrm{NOE}$, a small value of the ${ }^{3} \mathrm{C}_{\mathrm{C}^{\prime}-2^{\prime} \mathrm{OH}}$ coupling, and/or a large value of the ${ }^{3} \mathrm{JC}_{\mathrm{C}^{\prime}-2^{\prime} \mathrm{OH}}$ coupling. Finally, the conformation of the $2^{\prime}-\mathrm{OH}$ proton of $\mathrm{C} 19$ can only be restricted by the presence of the $2^{\prime}-\mathrm{OH}(i)-\mathrm{H} 6 / \mathrm{H} 8(i+1) \mathrm{NOE}$, because the heteronuclear ${ }^{3} J_{\mathrm{C}^{\prime}-2^{\prime} \mathrm{OH}}$ and ${ }^{3} \mathrm{~J}_{\mathrm{C}^{\prime}-2^{\prime} \mathrm{OH}}$ couplings could not be measured reliably for this nucleotide. In summary, our analysis reveals that the $\mathrm{H}_{2}^{\prime}-\mathrm{C}^{\prime}-\mathrm{O} 2^{\prime}-\mathrm{H}$ torsion angles of the canonical $A$-form lower stem nucleotides of the TAR-RNA populate both the base and the $\mathrm{O}^{\prime}$ domain, while the $\theta$ torsion angles of the bulged uridine residues show a clear preference for the $\mathrm{O}^{\prime}{ }^{\prime}$ domain.

A network of water-mediated hydrogen bonds anchored by the 2'-hydroxyl group has been proposed to stabilize the $A$-form RNA duplex. ${ }^{3}$ The results of our study are in excellent agreement with this model. The $2^{\prime}$-hydroxyl group in the base domain donates an $\mathrm{H}$-bond to a water molecule in the base plane, while the 2'-hydroxyl group projecting towards the $\mathrm{O}^{\prime}$ oxygen atom can accept an $\mathrm{H}$-bond from a water molecule in the same base plane (Figure $4(\mathrm{~b})$ ). In contrast, if the $2^{\prime}-\mathrm{OH}$ group adopted a conformation within the $\mathrm{O} 4^{\prime}$ domain, the lone pair electrons of the $\mathrm{O} 2^{\prime}$ oxygen atom would occupy an unfavorable orientation for their participation in an $\mathrm{H}$-bonding network involving water molecules located in the base plane. Consequently, the $2^{\prime}-\mathrm{OH}$ groups in the canonical $A$-form lower stem of the TAR-RNA never project into the $\mathrm{O}^{\prime}$ domain. Furthermore, we observe an alternating pattern of $\theta$ torsion angles in the base and in the $\mathrm{O}^{\prime}$ domain for $3^{\prime}$ and $5^{\prime}$-strand nucleotides in consecutive Watson-Crick G-C base-pair steps (5'-nucleotides 17-19 and 3'-nucleotides 43-45, respectively). Despite the limited statistical significance of this observation, such an alternating pattern with the $\mathrm{H} 2^{\prime}-\mathrm{C}^{\prime}-\mathrm{O}^{\prime}-\mathrm{H}$ torsion angle adopting base and $\mathrm{O}^{\prime}$ domain conformations is required to fully support the network of hydrogen bonds described in the crystal structures of the RNA duplex. ${ }^{3}$ In the crystal, the two water molecules spanning the minor groove share an $\mathrm{H}$-bond with each other and function as $\mathrm{H}$-bond donors to the functional $\mathrm{N} 3 / \mathrm{O} 2$ groups within the base moiety. To complete an uninterrupted chain of $\mathrm{H}$-bonds in the minor 
(a)

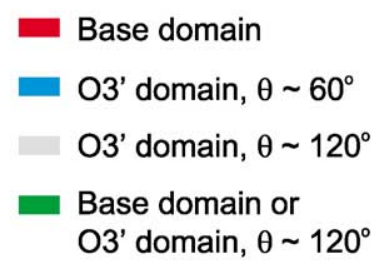

(b)

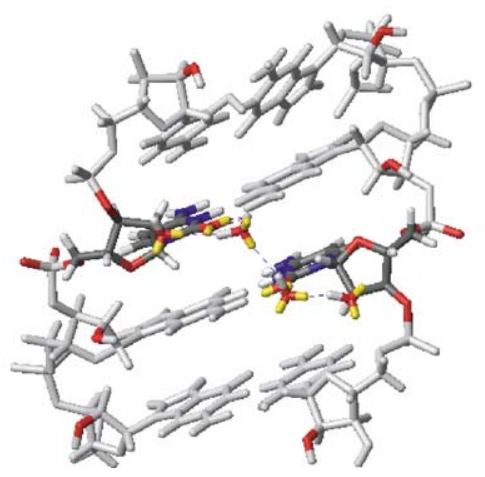

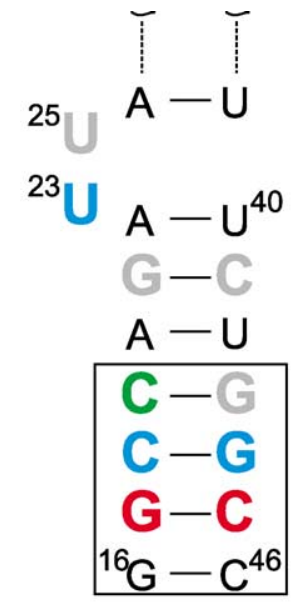

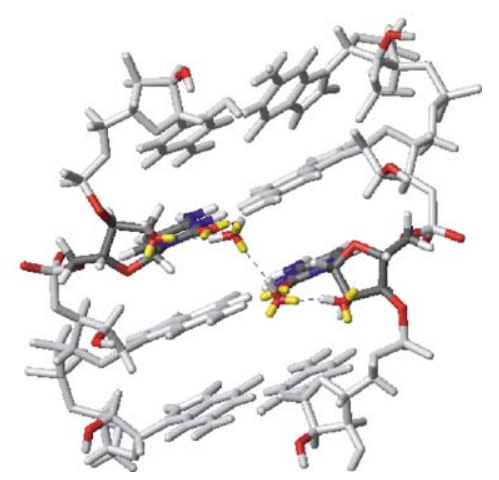

Figure 4. (a) Summary of the conformational preferences of the $\mathrm{H} 2^{\prime}-\mathrm{C}^{\prime}-\mathrm{O} 2^{\prime}-\mathrm{H}$ torsion angle $\theta$ of the cytidine and guanosine residues of the lower stem and bulged uridine residues of the HIV-2 TAR RNA. Both the base and the ${ }^{\prime}{ }^{\prime}$ domain are populated in an alternating manner, the bulged uridine residues show a clear preference for the $\mathrm{O}^{\prime}$ domain. Not a single $\mathrm{H} 2^{\prime}-\mathrm{C}^{\prime}-\mathrm{O}^{\prime}-\mathrm{H}$ torsion angle in the $\mathrm{O}^{\prime}$ domain was observed. The boxed four closing base-pairs of the lower stem are shown in (b). (b) Network of water molecules bridging the nucleotides $\mathrm{C} 18$ and $\mathrm{C} 45$ in the minor groove of the lower stem of the HIV-2 TAR RNA, modeled in an ideal $A$-form helix. Functionally important groups are colored: $\mathrm{C} 18$ and $\mathrm{C} 45$ base nitrogen atoms are shown in blue; $\mathrm{O} 2$ base, $\mathrm{O}^{\prime}$ backbone, and ribose $\mathrm{O} 2^{\prime}$ oxygen atoms are shown in red; lone pairs of water, $\mathrm{O} 2$ base, and ribose $\mathrm{O}^{\prime}$ ' oxygen atoms are colored yellow. One water molecule is situated in the base plane of C18, where it participates in an $\mathrm{H}-$ bond as proton donor with the $\mathrm{O} 2$ of the base and in an H-bond as proton acceptor with the $2^{\prime}-\mathrm{OH}$ (conformation in the $\mathrm{O}^{\prime}$ domain). The second water molecule is located in the plane of $\mathrm{C} 45$, where it participates as proton donor in an $\mathrm{H}$-bond with the $\mathrm{O} 2$ of the base and in an H-bond with the $2^{\prime}-\mathrm{OH}$ (conformation in the base domain). groove, one of the two water molecules must accept and one must donate an H-bond to the 2'-hydroxyl groups of nucleotides of opposite strands in consecutive base-pair steps (Figure 4(b)). The 2'-hydroxyl group can function as an $\mathrm{H}$-bond donor to a water molecule in the base plane when $\theta$ is in the base domain and, conversely, is able to accept a proton from the same water molecule when $\theta$ is in the $\mathrm{O}^{\prime}$ domain. The ideal network of H-bond spanning the minor groove, postulated on the base of the crystal structure of an RNA duplex, therefore requires that the $\mathrm{H}_{2}^{\prime}-\mathrm{C} 2^{\prime}-\mathrm{O} 2^{\prime}-\mathrm{H}$ torsion angles of two nucleotides belonging to opposite strands in base-pair steps assume alternating base and $\mathrm{O}^{\prime}$ domain conformations.

Interestingly, the solvent exchange rates of the 2'-OH protons of the bulge nucleotides U23 and U25 are similar to those of the cytidine and guanosine bases in the lower stem. The scalar coupling data for the 2'-hydroxyl groups of U23 and U25 can be interpreted assuming a single conformation where the proton points towards the phosphate backbone in the O3' domain. The TAR RNA bulge region is intimately involved in ligand binding events. The bulged nucleotides, which are relatively flexible in the free TAR RNA, assume a well-defined, rigid conformation upon argininamide or magnesium binding. ${ }^{32-34}$ The NMR experiments described here were conducted in the absence of any ligands and thus may indicate pre-organized local conformation of the riboses of U23 and U25. It should be noted that the phosphate group between U23 and A22 located at the junction of the bulge and lower stem is important for Tat binding in the major groove of TAR. ${ }^{35}$ Further studies that address the role of the 2'-hydroxyl group of uridine residues U23 and U25 in the specific recognition of positively charged ligands are ongoing.

Here, we present the first conformational analysis of the $\mathrm{H} 2^{\prime}-\mathrm{C}^{\prime}-\mathrm{O} 2^{\prime}-\mathrm{H}$ torsion angle in a mediumsized RNA using a combination of scalar J-coupling and NOE data. The results obtained here are in good agreement with both molecular dynamics calculations $^{17}$ and X-ray studies ${ }^{3}$ and confirm the fundamental role of the 2'-hydroxyl group in building a network of hydrogen bonds in the minor groove, which stabilizes the preferred canonical $A$-form geometry of RNA. These data have important implications for the future understanding of high-affinity recognition and discrimination of $A$-form-like geometries over canonical $B$-form or other helices in RNA-protein complexes. The methodology and experiments developed here are of general relevance to structural studies of RNAs and allow for an accurate determination of the location of the 2'-hydroxyl proton, which will 
help elucidate the fundamental role of the 2'-hydroxyl group in RNA function, ligand binding, and catalysis.

\section{Acknowledgements}

We thank D. Treiber for helpful comments on the manuscript. This work was supported by the Max Planck Gesellschaft, the Deutsche Forschungsgemeinschaft (SFB416, to T.C.) and the National Institutes of Health (AI040187, to M.H.).

\section{Supplementary Data}

Supplementary data associated with this article can be found, in the online version, at doi:10.1016/j. jmb.2005.11.043

\section{References}

1. Saenger, W. (1984). Principles of Nucleic Acid Structure. Springer Advanced Texts in Chemistry, Springer, New York.

2. Gyi, J. I., Lane, A. N., Conn, G. L. \& Brown, T. (1998). The orientation and dynamics of the $\mathrm{C}^{\prime}-\mathrm{OH}$ and hydration of RNA and DNA-RNA hybrids. Nucl. Acids Res. 26, 3104-3110.

3. Egli, M., Portmann, S. \& Usman, N. (1996). RNA hydration: a detailed look. Biochemistry, 35, 8489-8494.

4. Cheong, C., Varani, G. \& Tinoco, I., Jr (1990). Solution structure of an unusually stable RNA hairpin, 5'GGAC(UUCG)GUCC. Nature, 346, 680-682.

5. Williams, D. J., Boots, J. L. \& Hall, K. B. (2001). Thermodynamics of 2 -ribose substitutions in UUCG tetraloops. RNA, 7, 44-53.

6. Chastain, M. \& Tinoco, I. (1993). Nucleoside triples from the group-I intron. Biochemistry, 32, 14220-14228.

7. Lynch, S. R., Pelton, J. G. \& Tinoco, I. (1996). NMR assignment of a 2 '-hydroxyl proton from the UUCG tetraloop through long-range correlations with C-13. Magn. Reson. Chem. 34, S11-S17.

8. Doherty, E. A., Batey, R. T., Masquida, B. \& Doudna, J. A. (2001). A universal mode of helix packing in RNA. Nature Struct. Biol. 8, 339-343.

9. Nixon, P. L., Rangan, A., Kim, Y. G., Rich, A., Hoffman, D. W., Hennig, M. \& Giedroc, D. P. (2002). Solution structure of a luteoviral P1-P2 frameshifting mRNA pseudoknot. J. Mol. Biol. 322, 621-633.

10. Theimer, C. A., Blois, C. A. \& Feigon, J. (2005). Structure of the human telomerase RNA pseudoknot reveals conserved tertiary interactions essential for function. Mol. Cell. 17, 671-682.

11. Eckstein, F. \& Lilley, D. M. J. (1996). Nucleic acids and molecular biology. In Catalytic RNA (Eckstein, F. \& Lilley, D. M. J., eds), vol. 10, Springer, Berlin.

12. Gesteland, R. F., Cech, T. \& Atkins, J. F. (1999). The RNA World: The Nature of Modern RNA Suggests a Prebiotic RNA. Cold Spring Harbor monograph series, monograph 37, 2nd edit., Cold Spring Harbor Laboratory Press, Cold Spring Harbor, NY.

13. Doherty, E. A. \& Doudna, J. A. (2000). Ribozyme structures and mechanisms. Annu. Rev. Biochem. 69, 597-615.
14. Gordon, P. M., Fong, R., Deb, S. K., Li, N. S., Schwans, J. P., Ye, J. D. \& Piccirilli, J. A. (2004). New strategies for exploring RNA's 2'-OH expose the importance of solvent during group II intron catalysis. Chem. Biol. 11, 237-246.

15. Conte, M. R., Conn, G. L., Brown, T. \& Lane, A. N. (1996). Hydration of the RNA duplex r(CGCAAAUUUGCG)2 determined by NMR. Nucl. Acids Res. 24, 3693-3699.

16. Giedroc, D. P., Cornish, P. V. \& Hennig, M. (2003). Detection of scalar couplings involving 2'-hydroxyl protons across hydrogen bonds in a frameshifting mRNA pseudoknot. J. Am. Chem. Soc. 125, 4676-4677.

17. Auffinger, P. \& Westhof, E. (1997). Rules governing the orientation of the 2'-hydroxyl group in RNA. J. Mol. Biol. 274, 54-63.

18. Hennig, M., Fohrer, J. \& Carlomagno, T. (2005). Assignment and NOE analysis of 2'-hydroxyl protons in RNA: implications for stabilization of RNA A-form duplexes. J. Am. Chem. Soc. 127, 2028-2029.

19. Seelamgari, A., Maddukuri, A., Berro, R., de la Fuente, C., Kehn, K., Deng, L. W. et al. (2004). Role of viral regulatory and accessory proteins in HIV-1 replication. Front. Biosci. 9, 2388-2413.

20. Cavanagh, J. \& Rance, M. (1992). Suppression of crossrelaxation effects in TOCSYspectra via a modified dipsi2 mixing sequence. J. Magn. Reson. 96, 670-678.

21. Lippens, G., Dhalluin, C. \& Wieruszeski, J. M. (1995). Use of a water flip-back pulse in the homonuclear NOESY experiment. J. Biomol. NMR, 5, 327-331.

22. Acharya, P., Velikian, I., Acharya, S. \& Chattopadhyaya, J. (2001). Molecular modelling of 2'-OH mediated hydrogen bonding in ribonucleos (t)ides by NMR constrained AM1 and MMX calculations. Nucleos. Nucleot. Nucl. 20, 1211-1217.

23. Acharya, P. \& Chattopadhyaya, J. (2002). The hydrogen bonding and hydration of $2^{\prime} \mathrm{OH}$ in adenosine and adenosine 3'-ethyl phosphate. J. Org. Chem. 67, 1852-1865.

24. Vuister, G. W. \& Bax, A. (1993). Quantitative J correlation-a new approach for measuring homonuclear 3-bond $J(\mathrm{H}(\mathrm{N}) \mathrm{H}($ Alpha) coupling-constants in ${ }^{15} \mathrm{~N}$-enriched proteins. J. Am. Chem. Soc. 115, 7772-7777.

25. Scott, L. G., Tolbert, T. J. \& Williamson, J. R. (2000). Preparation of specifically $2 \mathrm{H}-$ and ${ }^{13} \mathrm{C}$-labeled ribonucleotides. Methods Enzymol. 317, 18-38.

26. Gueron, M. \& Leroy, J. L. (1995). Studies of base pair kinetics by NMR measurement of proton exchange. Methods Enzymol. 261, 383-413.

27. Snoussi, K. \& Leroy, J. L. (2001). Imino proton exchange and base-pair kinetics in RNA duplexes. Biochemistry, 40, 8898-8904.

28. Pan, Y. \& MacKerell, A. D., Jr (2003). Altered structural fluctuations in duplex RNA versus DNA: a conformational switch involving base pair opening. Nucl. Acids Res. 31, 7131-7140.

29. Giudice, E. \& Lavery, R. (2003). Nucleic acid base pair dynamics: the impact of sequence and structure using free-energy calculations. J. Am. Chem. Soc. 125, 4998-4999.

30. Fraser, R. R., Kaufman, M., Morand, P. \& Govil, G. (1969). Stereochemical dependence of vicinal $\mathrm{H}-\mathrm{C}-\mathrm{O}-\mathrm{H}$ coupling constants. Can. J. Chem. 47, 403-409.

31. Kalinowski, H.-O., Berger, S. \& Braun, S. (1988). Carbon 13 NMR Spectroscopy, Wiley, New york.

32. Zacharias, M. \& Hagerman, P. J. (1995). The bend in RNA created by the trans-activation response element 
bulge of human immunodeficiency virus is straightened by arginine and by Tat-derived peptide. Proc. Natl Acad. Sci. USA, 92, 6052-6056.

33. Brodsky, A. S. \& Williamson, J. R. (1997). Solution structure of the HIV-2 TAR-argininamide complex. J. Mol. Biol. 267, 624-639.

34. Pitt, S. W., Majumdar, A., Serganov, A., Patel, D. J. \& Al-Hashimi, H. M. (2004). Argininamide binding arrests global motions in HIV-1 TAR RNA: comparison with $\mathrm{Mg}^{2+}$-induced conformational stabilization. J. Mol. Biol. 338, 7-16.

35. Hamy, F., Asseline, U., Grasby, J., Iwai, S., Pritchard, C., Slim, G. et al. (1993). Hydrogen-bonding contacts in the major groove are required for human-immunodeficiency-virus yype-1 Tat protein recognition of Tar RNA. J. Mol. Biol. 230, 111-123.

36. Geen, H. \& Freeman, R. (1991). Band-selective radiofrequency pulses. J. Magn. Reson. 93, 93-141.

Edited by M. F. Summers

(Received 24 August 2005; received in revised form 9 November 2005; accepted 14 November 2005) Available online 1 December 2005 